Special issue of the 3rd International Conference on Computational and Experimental Science and Engineering (ICCESEN 2016)

\title{
Production and Characterization of Niobium Toughened Ti-TiAl 3 Metallic-Intermetallic Composite
}

\author{
T. YENER* AND S. ZEYTIN \\ Sakarya University, Metallurgy and Materials Department, Sakarya, Turkey
}

\begin{abstract}
$\mathrm{Ti}^{-} \mathrm{TiAl}_{3}$ in situ composites with $10 \mathrm{wt} . \% \mathrm{Nb}$ were successfully prepared from $\mathrm{Ti}, \mathrm{Al}$, and $\mathrm{Nb}$ metallic powders by powder metallurgy processing technique of electric current activated/assisted sintering. The current and process time used for producing metallic-intermetallic composites were $2000 \mathrm{~A}$ and $90 \mathrm{~s}$, respectively. In terms of fracture toughness, effects of addition of ductile niobium phase to Ti-TiAl 3 composites were investigated. According to SEMEDS and XRD results, the synthesized composites mainly consisted of $\mathrm{TiAl}_{3}$ matrix and dispersive $\mathrm{Nb}$ reinforcing phases, as well as ductile Ti phases. Hardness and fracture toughness values of the samples were measured by Vickers hardness tester under loads of $100 \mathrm{~g}$ and $10 \mathrm{~kg}$, respectively. Fracture toughness value of $\mathrm{TiAl}_{3}$ intermetallic composites was increased with $\mathrm{Nb}$ ductile phase addititon from $1.69 \pm 0.05 \mathrm{MPam}^{1 / 2}$ to $5.23 \pm 0.3 \mathrm{MPa} \mathrm{m}^{1 / 2}$.
\end{abstract}

DOI: 10.12693/APhysPolA.132.941

PACS/topics: $46.50 .+\mathrm{a}, 72.80 . \mathrm{Tm}$

\section{Introduction}

Intermetallics are materials which have a sequential order of mixed atomic species of metal, metal or metalsemimetal species with nearly stoichiometric composition, such as for example, $\mathrm{Ni}_{3} \mathrm{Al}, \mathrm{FeAl}$, TiAl, $\mathrm{MoSi}_{2}$. Here, nickel (Ni), iron (Fe), titanium (Ti) and molybdenum (Mo) play the role of metallic component and aluminum (Al) or silicon $(\mathrm{Si})$ of metal/semimetal. In such cases, the metal-to-metal or metal-to-semimetal association is partially metallic and partially covalent (or ionic) in nature. There are also important intermetallic compounds of the metal-metal combinations, which are especially responsible for the atomic size differences that are unregulated for the Laves phases [1-3].

Among the intermetallics, titanium aluminide intermetallic compounds have received considerable attention recently due to their exceptional properties, such as high yield strength at elevated temperatures, improved creep properties, high oxidation and corrosion resistance, low density and good dimensional stability [4-7]. However, the biggest problem with these materials is the lack of ductility at conventional production temperatures [8]. Low room temperature ductility limits the use of intermetallics and leads to their production by costly production methods $[6,8-11]$.

In this study, we aimed to increase the room temperature ductility by producing metallic reinforced composite with intermetallic matrix. Unlike the previous studies, we have produced Ti-TiAl3 composite with in situ production technique and reinforced ductility by reinforcing it with $\mathrm{Nb}$. Phases were determined from XRD following the manufacturing process. Composites were analyzed by XRD technique using $\mathrm{Cu} \mathrm{K}_{\alpha}$ radiation with

*corresponding author; e-mail: tcerezci@sakarya.edu.tr a wavelength of $1.5418 \AA$ [12], in order to determine the phases formed in the body of the composite. Surfaces of materials were analyzed by SEM. The EDS analysis revealed how much of the element there was in the sample (weight percent). The Archimedes principle was used for density determination and the Vickers hardness test for hardness measurements. We have applied a load of $98 \mathrm{~N}$ for the fracture toughness measurement and determined the fracture toughness value using the Evans Charles equation.

\section{Materials and methods}

Powder materials of titanium (99.5\% purity, 35$44 \mu \mathrm{m}$ ), aluminum (99.8\% purity, 35-44 $\mu \mathrm{m}$ ) and niobium (99.5\% purity, $35-44 \mu \mathrm{m})$ were used as starting materials for manufacturing of $\mathrm{Ti}-\mathrm{Nb}-\mathrm{TiAl}_{3}$ metallic intermetallic compound. $\mathrm{Ti}, \mathrm{Al}$ and $\mathrm{Nb}$ powders were mixed for 30 minutes. After ball milling process, powder mixture was cold-pressed before sintering, to form a cylindrical compact in a metallic die under a uniaxial pressure of $200 \mathrm{MPa}$. Dimensions of the compact were $15 \mathrm{~mm}$ diameter and $5 \mathrm{~mm}$ thickness. The production of intermetallic compound was performed via electric current activated sintering technique in an open atmosphere at $2000 \mathrm{~A}$, for $90 \mathrm{~s}$. Process parameters are listed in Table I.

TABLE I

Process parameters for the samples.

\begin{tabular}{c|c|c|c|c}
\hline \hline $\begin{array}{c}\text { Sample } \\
\text { code }\end{array}$ & Wt.\% & $\begin{array}{c}\text { Current } \\
{[\mathrm{A}]}\end{array}$ & $\begin{array}{c}\text { Voltage } \\
{[\mathrm{V}]}\end{array}$ & $\begin{array}{c}\text { Holding } \\
\text { time [s] }\end{array}$ \\
\hline $\begin{array}{c}\mathrm{R} \\
\text { (Reference) }\end{array}$ & $38 \mathrm{Ti}-62 \mathrm{Al}$ & 2000 & $0.9-1.2$ & 120 \\
$\mathrm{C}-10 \mathrm{Nb}$ & $45 \mathrm{Ti}-45 \mathrm{Al}-10 \mathrm{Nb}$ & 2000 & $0.9-1.2$ & 90
\end{tabular}

\section{Characterization}

The morphologies of the samples and the presence of the phases formed were examined by scanning electron 
microscopy (SEM-EDS). X-ray diffraction (XRD) analysis, using $\mathrm{Cu} \mathrm{K} \mathrm{K}_{\alpha}$ radiation with a wavelength of $1.5418 \AA$ over a $2 \theta$ range of $10-80^{\circ}$, was also carried out. The micro-hardness of the test materials was measured using Vickers indentation technique with a load of $0.98 \mathrm{~N}$ using Leica WMHT-Mod model Vickers hardness measurement instrument. Evans-Charles equation [13-15] was used for fracture toughness calculations.

$$
K_{\text {Ic }}=0.0824 \frac{P}{c^{3 / 2}},
$$

where $K_{\text {Ic }}$ is the fracture toughness, $P$ is the load and $c$ is the crack length. Crack lengths were immediately measured by an optical micrometer attached to the optical microscope. Tests were repeated three times under the same conditions to ensure the reproducibility of the fracture toughness data.

\section{Results and discussion}

\subsection{SEM-EDS analyses}

The morphologies of as-received $\mathrm{Ti}, \mathrm{Al}$ and $\mathrm{Nb}$ powders are shown in Fig. 1. The metallic $\mathrm{Al}$ powder particles were generally spherical with a diameter of $10 \mu \mathrm{m}$ in size. Some of the particles are agglomerated, however are finer than 35-40 $\mu \mathrm{m}$. In contrast, the $\mathrm{Ti}$ and $\mathrm{Nb}$ powder grains had sharp irregular corners and were finer than $40 \mu \mathrm{m}$ in size.

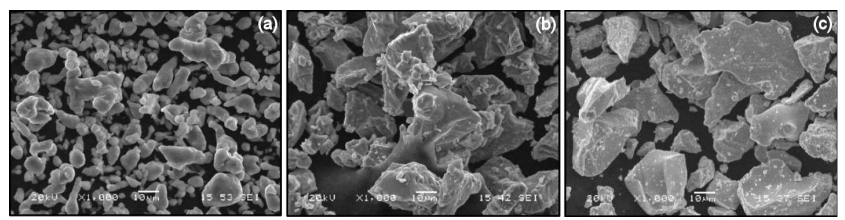

Fig. 1. SEM micrographs of (a) Al, (b) $\mathrm{Ti}$, (c) $\mathrm{Nb}$ powders.
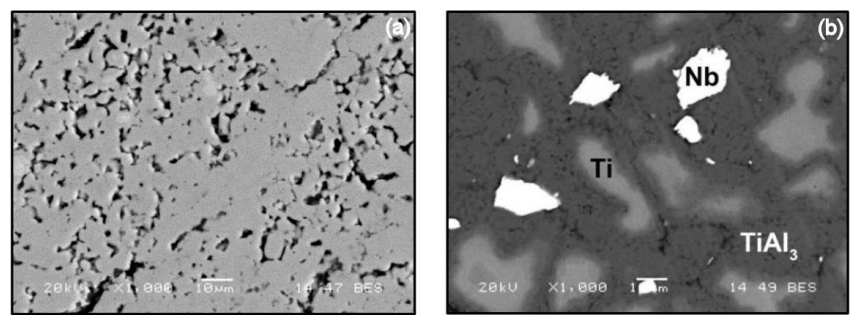

Fig. 2. SEM migrographs of sintered (a) $\mathrm{TiAl}_{3}$ (R), (b) $\mathrm{Ti}-\mathrm{Nb}-\mathrm{TiAl}_{3}(\mathrm{C}-10 \mathrm{Nb})$.

SEM micrograph of the sintered $\mathrm{TiAl}_{3}$ sample produced during 120 seconds at $2000 \mathrm{~A}$, using the starting powders of $\mathrm{Ti}$ and $\mathrm{Al}$, is shown in Fig. 2a. The image of the $\mathrm{Ti}-\mathrm{Nb}-\mathrm{TiAl}_{3}$ sample, which was produced by supplementing $10 \mathrm{wt} . \% \mathrm{Nb}$ to the reference composition is shown in Fig. 2b. The conversion of $\mathrm{TiAl}_{3}$ is expected to take 120 seconds to complete, while the ductile phase effect is considered sufficient for the desired titanium phase to remain in the structure for 90 seconds. Nb, the reinforcing phase, remained visible as a bright white phase.
$\mathrm{TiAl}_{3}$ phase was determined as the predominant phase, while composites were seen as titanium light gray islets. SEM-EDS analyses also support these results (Fig. 3).
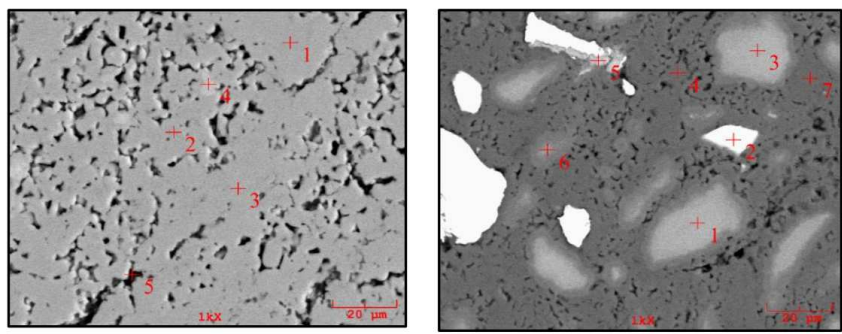

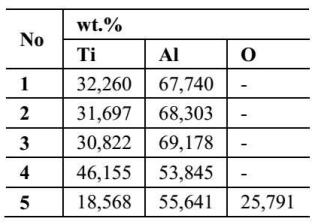

(a)

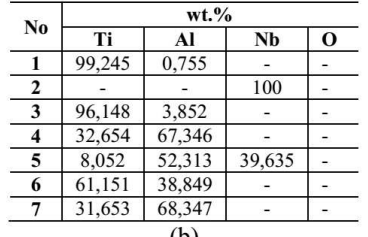

(b)
Fig. 3. SEM-EDS analyses of (a) $\mathrm{TiAl}_{3}$ (R), (b) Ti$\mathrm{Nb}-\mathrm{TiAl}_{3}(\mathrm{C}-10 \mathrm{Nb})$.

\subsection{X-ray analysis}

The main phase in $\mathrm{R}$ composites is $\mathrm{TiAl}_{3}$, whereas $\mathrm{C}$ $10 \mathrm{Nb}$ composite contains $\mathrm{Nb}, \mathrm{Ti}$ and $\mathrm{TiAl}_{3}$, as shown in XRD graph in Fig. 4. A small amount of oxygen is also detected from XRD analyses.
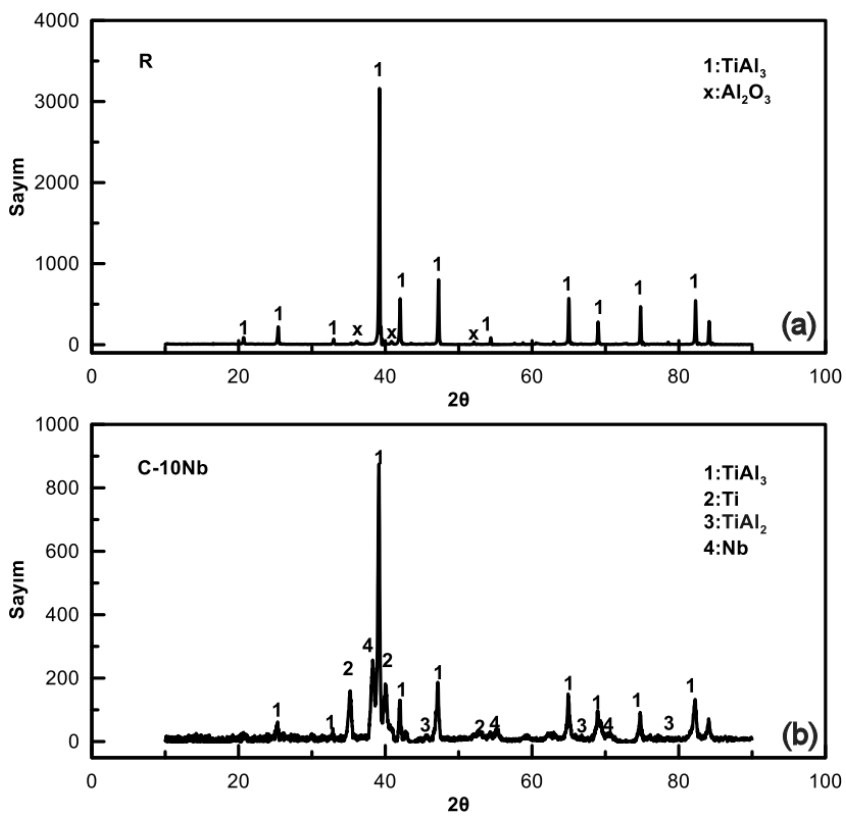

Fig. 4. XRD analyses of (a) $\mathrm{TiAl}_{3}$ (R), (b) Ti-Nb$\mathrm{TiAl}_{3}(\mathrm{C}-10 \mathrm{Nb})$.

\subsection{Hardness and fracture toughness}

The hardness values of samples were $460 \pm 25$ and $380 \pm 45 \mathrm{HV}$ for $\mathrm{R}$ and $\mathrm{C}-10 \mathrm{Nb}$ respectively. With the increasing metallic phase the hardness of the composites has decreased from $460 \mathrm{HV}$ to $380 \mathrm{HV}$ (Table II). 
This decrease in hardness is acceptable. When it comes to fracture toughness values of the samples an increment from 2.15 to $5.23 \mathrm{MPa} \mathrm{m}^{1 / 2}$ can be seen. A two times increase in fracture toughness with niobium reinforcement has been obtained.

\section{TABLE II}

Hardness and fracture toughness values of $\mathrm{R}$ and $\mathrm{C}-10 \mathrm{Nb}$ samples.

\begin{tabular}{c|c|c}
\hline \hline Sample & $\begin{array}{c}\text { Hardness } \\
{[\mathrm{HV}]}\end{array}$ & $\begin{array}{c}\text { Fracture toughness } \\
{\left[\mathrm{MPa} \mathrm{m}^{1 / 2}\right]}\end{array}$ \\
\hline $\mathrm{R}$ & $460 \pm 25$ & $2.15 \pm 0.05$ \\
$\mathrm{C}-10 \mathrm{Nb}$ & $380 \pm 45$ & $5.23 \pm 0.3$
\end{tabular}

\section{Conclusions}

- Nb-Ti-TiAl 3 in-situ composites were manufactured successfully by one-step electric current activated/assisted sintering method during 90 seconds in a steel mould without using any inert gas or vacuum medium.

- The presence of $\mathrm{Ti}, \mathrm{Nb}$ and $\mathrm{TiAl}_{3}$ phases were verified by XRD and SEM-EDS analysis.

- $\mathrm{TiAl}_{3}$ intermetallic sample, produced during 120 seconds, has remarkably high hardness values, as much as $460 \mathrm{HV}$, whereas ductile-phasereinforced $\mathrm{Nb}-\mathrm{Ti}-\mathrm{TiAl}_{3}$ composite has hardness value of $380 \mathrm{HV}$.

- A two times increase in the fracture toughness values has been obtained with niobium reinforcement.

\section{Acknowledgments}

The authors thank Prof. Dr. Cuma Bindal and expert Fuat Kayis for performing XRD and SEM-EDS studies and special appreciation is expressed to technicians Ersan Demir and Erkut Tas of Sakarya University for assisting with experimental studies.

\section{References}

[1] D. Morris, M. Munoz-Morris, Revista de Metalurgia 41, 498 (2005).

[2] N. Ergin, O. Ozdemir, Acta Phys. Pol. A 127, 1103 (2015).

[3] N. Ergin, G. Yoruk, O. Ozdemir, Acta Phys. Pol. A 123, 245 (2013).

[4] R. Reddy, A. Yahya, L. Brewer, J. Alloys Comp. 321, 223 (2001).

[5] J. Sienkiewicz, S. Kuroda, R.M. Molak, H. Murakami, H. Araki, S. Takamori, K.J. Kurzydłowski, Intermetallics 49, 57 (2014).

[6] S. Vaucher, M. Stir, K. Ishizaki, J.M. Catala-Civera, R. Nicula, Thermochim. Acta 522, 151 (2011).

[7] T. Wang, J. Zhang, Mater. Chem. Phys. 99, 20 (2006).

[8] M. Mirjalili, M. Soltanieh, K. Matsuura, M. Ohno, Intermetallics 32, 297 (2013).

[9] T. Marr, J. Freudenberger, A. Kauffmann, J. Romberg, I. Okulov, R. Petters, J. Scharnweber, A. Eschke, C.-G. Oertel, U. Kühn, J. Eckert, W. Skrotzki, L. Schultz, Metals 3, 188 (2013)

[10] P.-Y. Wang, H.-J. Li, L.-H. Qi, X.-H. Zeng, H.-S. Zuo, Prog. Nat. Sci.: Mater. Int. 21, 153 (2011).

[11] T. Yener, S.C. Yener, S. Zeytin, Mater. Tehnol. 50, 899 (2016).

[12] T. Yener, I. Altinsoy, S.C. Yener, G.F. Celebi Efe, I. Ozbek, C. Bindal, Acta Phys. Pol. A 127, 1045 (2015).

[13] E. Ercenk, U. Sen, S. Yilmaz, Surf. Coat. Technol. 232, 703 (2013)

[14] E. Ercenk, U. Sen, S. Yilmaz, Tribol. Int. 52, 94 (2012).

[15] A.S. Demirkiran, S. Yilmaz, U. Sen, J. Ceram. Proc. Res. 14, 51 (2013). 